DOI: 10.15393/j2.art.2015.2941

Article

\title{
Impact of the EU Timber Regulation on Russian companies exporting wood and wood-based products
}

\author{
Elena V. Neshataeva ${ }^{1, *}$, Timo Karjalainen ${ }^{2,3}$ \\ ${ }^{1}$ Saint-Petersburg State Forest-Technical University, 194021, Saint-Petersburg, Institutskiy per. 5; \\ E-mail: elenamp329@mail.ru (E.N.) \\ 2 Natural Resources Institute Finland (Luke), P.O. Box 68, 80101 Joensuu, Finland; Email: \\ timo.j.karjalainen@luke.fi (T.K.) \\ ${ }^{3}$ University of Eastern Finland, Faculty of Science and Forestry, School of Forest Sciences, P.O. \\ Box 111, 80101, Joensuu, Finland; Email: timo.karjalainen@uef.fi \\ * Author to whom correspondence should be addressed; Email: elenamp329@mail.ru (E.N.); \\ Tel.: +7 90464507 93; Fax: +7(812) 6708117
}

Received: 6 February 2015 / Accepted: 27 Jun 2015/ Published: 10 July 2015

\begin{abstract}
The problem of illegal logging forced EU, which is one of the major consumers of wood in the world, to develop legislation aimed at termination of supplies of illegally harvested wood and wood-based products into EU. EU Timber Regulation №995 is applicable for any company placing wood or wood-based products on the EU market. Russia ranks first in illegally harvested timber export into EU markets, therefore EU Timber Regulation should influence substantially on Russian companies. Possible influence of the EU Timber Regulation on Russian companies was analyzed based on a questionnaire sent to Russian companies exporting wood and wood-based products. Analyses were supplemented by a literature review and expert's opinion.

Results from the questionnaire show that Russian companies are not going to stop export of wood and wood-based products into EU because of the EU Timber Regulation. They plan to revise their suppliers and internal company documentation and documentation from suppliers. Exporting companies plan to stop business with some of the suppliers and replacing by new suppliers is not obligatory. This means that export of wood and wood-based products may decrease.
\end{abstract}

Keywords: export of wood; export of wood-based products; illegal logging; origin of wood; tracing systems; EU Timber Regulation; Russia 


\section{Introduction}

Illegal logging is a global problem for many forested countries. The term "illegal logging" means harvesting, transporting, processing, buying and selling of wood with violation of national or subnational laws [1]. Some countries are trying to solve the problem of illegal logging gradually. There are already several national programs directed to prohibition of illegally harvested timber entering their markets, such as US Lacey Act, EU Timber Regulation, and Australian Illegal logging Prohibition Act. Increasing number of consumers in developed countries, including companies, governments and final customers are concerned about legality of wood or wood-based products they buy. Therefore companies and governments have supported development of procurement programs, forest certification, chain of custody and wood origin-tracing systems to tackle illegal harvesting and trade.

European Union (EU) is one of the major consumers of timber and wood-based products in the world. EU internal roundwood removal (including roundwood and firewood) in 2012 was about 430 million $\mathrm{m}^{3}$ [2], but it was not enough for the demand and thus EU is a net importer of wood. In 2013 the volume of imported industrial roundwood to EU was around 52 million $\mathrm{m}^{3}$ and export of industrial roundwood from EU was around 38 million $\mathrm{m}^{3}$ [2].

Wood may come to EU from countries, which possibly have weaker control over wood origin. It is estimated that 26 to 31 million $\mathrm{m}^{3}$ of the wood-based products, which are imported from non EU countries, comes from illegal sources, for example Russia, Indonesia, China, Brazil and others. Almost half of the illegal wood has been claimed to come from Eastern Europe, North Asia and the Balkans [3].

EU Timber Regulation №995 (EUTR), aiming to terminate supplies of illegally harvested wood and wood-based products into EU, came into force in March 2013 and is applicable for any company (Operator) who places timber into EU market. The European Commission plans to analyze effectiveness of EUTR's implementation in March 2015 and henceforth each 6 years [4]. However, EUTR already influences traders of wood or wood-based products. Taking into account that some of the wood and wood-based products in Russia may have illegal origin and that Russia is one of the major exporters of roundwood into EU, it is expected that EUTR will influence Russian companies exporting wood and wood-based products into EU.

The aim of this research was to study possible impacts of the EUTR on the Russian companies exporting wood and wood-based products to the EU. The hypothesis was that the number of Russian exporting companies or suppliers of such companies would decrease due to the implementation of the EUTR. A hypothesis is that some exporters of wood or wood-based products will leave the supply chain from Russia to the EU countries because they will not be able to prove legality of wood.

\section{Materials and Methods}

The first part of the research is focused on reviewing literature related to systems, which could help implementation of the EUTR in Russia. The main obligations for Operators are to work with Due Diligence System (DDS). DDS should minimize the risk of placing illegally harvested wood or wood products containing illegally harvested wood to the EU market. DDS includes three key elements: Information (what kind of timber, country of origin, quantity, information about suppliers); Risk assessment and Risk mitigation [5]. Systems which could be used for DDS include voluntary certification schemes, tracing systems of wood origin and Russian national legislation. These systems combat illegal logging and possibly could be used for the needs of the EUTR. 
The second part of the research was to determine the impact of the EUTR on the Russian exportoriented forest companies:

- $\quad$ Possible decrease in the number of export-oriented forest companies;

- Possible decrease in the number of suppliers of export-oriented forest companies;

- Internal changes in business practices of export-oriented forest companies.

Changes in the number of export-oriented companies could be analyzed comparing the number of companies which exported wood and wood-based products into EU at the end of 2012 and 2013. Change in the total number of exporters could be related not only to impacts of the EUTR but also to other reasons. Data about changes in the number of suppliers and in internal operations in a company can be obtained only directly from the company. Therefore questionnaire was prepared and sent out to Russian forest companies who export wood and wood-based products into EU. Web service virtualexs.ru which can be used for marketing surveys was used and questionnaire was sent to the companies at the end of 2013.

First questions were to get basic information about the company, including size and exported products. The rest of the questions asked if companies have received any requirements related to the EUTR implementation from the Operators, and if companies have to do any extra actions related the EUTR implementation and what kind of actions if any? A few questions were aimed at determining companies' opinion about the possibility to fulfill the EUTR requirements through voluntary forest certification, internal system for tracing wood origin and through implementation of the new amendments to the forest code related to the state control of turnover of roundwood [16].

Questionnaires were filled in anonymously because it is the only possible way to get honest answers from companies. Questionnaires were distributed to about 500 Russian companies exporting roundwood, processed wood, pulp and paper to EU.

Altogether 35 answers were received, and 27 of them belonged to the target group, companies exporting timber or timber products into EU. Such amount of answers does not allow reaching high confidence level of research. Sample size is calculated using formula 1 and 2 [6]. According to formula 1 in case of $\mathrm{z}^{2}=1$, table value 44 for confidence level is $85 \%, \mathrm{P}=0,5 ; \mathrm{C}=13 \%, \mathrm{SS}=30,6$ respondents. And according to formula 2 for population (Pop) less than 50000 , Pop=500, New SS= 28,9 .

$$
S S=\frac{Z^{2} * P *(1-P)}{C^{2}}
$$

Formula 1. Calculation of sample size for general population greater than 50,000 [6].

Where: SS $=$ Sample Size

$\mathrm{Z}=\mathrm{Z}$-value

$\mathrm{P}=$ Percentage of population picking a choice, expressed as decimal (on default)

$\mathrm{C}=$ Confidence interval, expressed as decimal

$$
\text { New SS }=\frac{S S}{1+\frac{S S-1}{P o p}}
$$

Formula 2. Calculation of sample size for general population less than 50,000[6].

Consequently, derived sample size of 27 answers approximately corresponded to $85 \%$ confidence level and 13\% confidence interval. This means that in about $85 \%$ of the cases other unexamined 27 companies will give the same answers. Confidence interval means that quantitative results derived from the sample will fluctuate $\pm 13 \%$. For example, if $15 \%$ of responded companies intended to stop export, confidence interval $\pm 13 \%$ means that in fact $2 \%$ to $28 \%$ of the companies 
intended to stop export. Such a big margin of error means that quantitative analysis is not desirable. Consequently, analysis generally has a qualitative character.

It should be noted that the assumed number of exporting companies was 500. Some of them may not exist anymore, and some may sell very small amounts of wood or wood-based products. Therefore, the number of operating companies is most likely less than 500. Consequently, confidence interval could be less than $13 \%$ and confidence level could be more than $85 \%$. Therefore decrease in the total population and increase of accuracy are possible, this research may also include quantitative results. Russian export revenues for wood and wood-based products were $\$ 3,5$ billion in 2010 to the EU countries (\$1 equal to 31 rubles)[7]. Aggregate annual income of the companies who returned the questionnaire was more than 13 billion rubles, which was about $12 \%$ of the Russian total annual export earnings from export of wood and wood-based products to Europe. This fact allows us to conduct some quantitative analysis.

About $40 \%$ of the companies were large based on their turnover (over 1 billion rubles per year), $45 \%$ SMEs (small and medium-sized enterprises) and the rest ones were micro enterprises (turnover less than 60 million rubles per year). Nearly $80 \%$ of the companies were exporting processed wood, $10 \%$ roundwood and $10 \%$ pulp and paper. Nearly half of the companies $(45 \%)$ sourced wood both from their own harvesting operations and from suppliers, one third used only suppliers and $22 \%$ got all wood from their own harvesting operations.

\section{Results}

In Russia there are two voluntary certification schemes, Program for the Endorsement of Forest Certification (PEFC) and Forest Stewardship Council (FSC) certification. First certificates in Russia were issued in 2000 by FSC and the number of certificates grows. By 2011 already 300 FSC certificates (both forest management and supply chain) and 5 PEFC certificates were issued, covering totally almost 30,2 million hectares[7]. More than half of the certified forest land is located in the European part of Russia. Today almost all large-sized Russian export-oriented companies are certified.

Voluntary forest certification was designed to consistently improve the process of forest utilization and management. Certification can help also combating illegal logging because of increasing ecological responsibility, monitoring of wood origin, and traceability of processed wood products.

Prior to implementation of the EUTR the majority of publications either expressly or implicitly described a possibility to use voluntary forest certification as a due diligence system required by the EUTR [7]. Voluntary forest certification, which is highly compliant with the EUTR, however is not a pass ticket to the EU markets. Possibility to use certification as a tool to comply with the EUTR requirement is mentioned in the regulation: «In order to recognize good practice in the forestry sector, certification or other third party verified schemes that include verification of compliance with applicable legislation may be used in the risk assessment procedure» [8]. Since DDS contains not only risk assessment, but also information and risk mitigation parts, forest certification does not fully meet the requirements. Despite that, more than half of the Russian exporting companies who responded to the questionnaire believe that voluntary forest certification is a sufficient tool to meet the EUTR requirements.

Wood origin tracing systems, which are common for most of the international companies operating in Russia, are focused on objective evidence of the legality of wood and products manufactured from the wood. Thus, the aims of wood origin tracing system and the EUTR are the same, namely to prevent illegally harvested timber to enter the market. According to the EUTR, third party verified schemes that include verification of compliance with applicable legislation can 
be used in risk assessment procedure. That is the reason why existence of company's wood origin tracing system can simplify the development of DDS by the Operator. According to the questionnaire results around $95 \%$ of the companies who have their own wood origin tracing system believe that their tracing system already complies with the EUTR's requirements.

Besides certification and verification schemes or requirements of ecologically sensitive market, state control of illegal logging is one of the major forces in combating illegal logging. Among other control measures the Amendments to the Forest Code may be noted being related to combating illegal logging and to control wood turnover which came into force in December 2013 [9].

New requirements related to amendments to the Forest Code deserve high attention because this act potentially could become an initial part of the DDS. Those amendments include the following developments[9]:

- Introduction of Unified State Automated Information System of round wood turnover;

- Obligatory declaration of round wood turnover before its processing;

- Liability for violation of legislation about turnover of round wood and possibility for expropriation of wood in case of such violation;

- Obligatory marking of wood assortment of valuable tree species;

- Presence of a special accompanying document for transportation of wood;

- Prohibition for citizens to sell round wood procured for their own needs.

Data required according to those amendments are partially the same as data required for the DDS. For example: place of harvest, name and address of logging company, number of lease agreement, information indicating compliance of round wood with the applicable legislation such as allowed felling volume, documents entitling to realize wood procurement.

Slightly more than half of the respondents (around 51\%) did not believe that the Amendments to the Forest Code would completely ensure legality of wood origin. Other respondents either considered that the Amendments described above are enough to prove legality of wood origin or had no opinion.

EUTR places the onus on the Operators to control legality of wood origin. Therefore most of the Operators require Russian wood exporters to verify legality of wood origin.

According to answers obtained from the questionnaire, about $20 \%$ of the respondents did not get any request from Operators in the EU. Considering $\pm 13 \%$ confidence interval, the number of such companies range from $7 \%$ to $33 \%$. On the other hand, the majority of the exporting companies (67 to $93 \%$ ) already know about Operator's demands related to implementation of the EUTR. Large share of export companies informed about the EUTR's requirements is a reflection of the fact that most of the Operators take seriously the necessity to implement the EUTR's requirements and work carefully on it.

The questionnaire included questions related to determining possible impact of the EUTR on the exporting companies. Due to the necessity to implement requirements of the EUTR some of the exporters should take measures to prove legality of wood origin for the Operators, but for other exporters requirements of the EUTR do not lead to any changes in usual business practice. The results of the questionnaire also suggested that some of the companies will even stop export because of impossibility to prove legality.

As a result of the questionnaire, $65 \%( \pm 13 \%)$ of the companies did not see any need for additional actions to implement requirements of the EUTR. That means that the major part of the exporters does not need to spend time or resources to meet the requirements established by the Operator.

Smaller share of the exporters needs to implement some actions to meet the requirements established by the Operator. The results of the questionnaire suggested several options for actions related to implementation of the requirements of the EUTR. 
Nearly $60 \%$ of those companies who plan to take different kinds of actions related to implementation of the requirements of the EUTR responded that they were going to reject suppliers, which were not able to meet the requirements. Also, as expected, almost half of the respondents answered that all what they needed to do in terms of implementation of the requirements of the EUTR was to prepare extra documentation to prove legality of wood and to provide the same kind of papers from their own suppliers. Action options "start voluntary forest certification procedure" and "start to build tracing system for wood origin" were not chosen. No possible actions outside suggested options were given by respondents in the questionnaire.

Those companies who are going to reject some of their suppliers are ready to reject on average around $51 \%( \pm 13 \%)$ of the suppliers (Table 1). Four companies have in total 90 suppliers, and 51 of them would be rejected. It should be noted that one company was going to reject all suppliers (Company 1) and another (Company 4 ) only $25 \%$ of the suppliers.

Table 1. Number of suppliers rejected by exporters related to implementation of the EUTR requirements

\begin{tabular}{|c|c|c|c|}
\hline Company & Number of suppliers & $\begin{array}{c}\text { Number of suppliers } \\
\text { planned to be rejected }\end{array}$ & $\begin{array}{c}\% \text { of suppliers planned } \\
\text { to be rejected }\end{array}$ \\
\hline Company 1 & 3 & 3 & 100 \\
\hline Company 2 & 50 & 20 & 40 \\
\hline Company 3 & 25 & 20 & 80 \\
\hline Company 4 & 12 & 3 & 25 \\
\hline Sum & 90 & 46 & 51 \\
\hline
\end{tabular}

About half of the companies plan to search for new suppliers and the rest plan to reduce the volume of export. It is difficult to predict decrease in total exporting volume of wood and woodbased products based on the current questionnaire. However, it is clear that export of wood and wood based products from Russia is expected to decrease due to implementation of the EUTR. Such decreasing is related to the reduction of the number of suppliers who are not able to prove legality of wood origin.

\section{Discussion and Conclusions}

The study revealed that none of the respondents plan to stop export of timber into the European Union. However, some of the companies who are forced to make some actions for meeting the requirements of the EUTR are going to decline services of some of their wood suppliers. Conscientious forest loggers and wood processing companies who are operating in accordance with the Russian legislation and who have possibility to prove legality of their actions have opportunities to find new customers represented by Russian timber exporters. Such companies also have opportunities to come into the EU market themselves. Possibility to come into the EU market for such companies could be also explained by the fact that some of the exporters who are going to reduce the number of their suppliers do not plan to search new suppliers, but plan to reduce the volume of export.

It should be understood that those suppliers who have been abandoned, will not cease to exist and will not stop illegal logging if there is any. They will reorient to internal Russian market. Therefore, the EUTR could only stop supplies of illegally logged wood to the European market, but the overall problem of illegal logging in Russia will not be influenced.

Currently high expectations are placed on the amendments of the Forest Code related to verification of the legality of harvested roundwood. 
According to the questionnaire, Russian exporters plan to take the following actions to meet the requirements of the EUTR:

- Partial cancellation of supplier's services;

- Detailed modification of internal documentation and supplier's documentation.

None of the respondents specified implementation of voluntary forest certification or development of internal wood origin tracing systems as planned actions. This may be due to:

- Implementation of voluntary certification procedure requires sizable intellectual and material inputs. Despite benefits in the form of increase in the price of product or bigger possibilities for sales, lots of exporters could manage without certificate. And since the certificate cannot completely fulfill the requirements of the EUTR, companies prefer to confine themselves and find cheaper options for meeting the requirements.

- As noted by the Development Director of one major Russian forest industry company "Ilim Pulp Enterprise" (Dmitry Chuiko), development of the internal wood origin tracing system is easier for large enterprises where the costs per unit are significantly lower due to the volume of production [10]. The majority of such enterprises already have their own tracing systems for wood origin.

Nowadays in Russia there are companies that developed their own Due Diligence Systems because they see them as the only possible system to completely fulfill the requirements of the EUTR. One of the examples is OOO Sveza-les. Their DDS is highly evaluated and recognized by a controlling unit in Germany [11].

Also in Russia there are certification bodies that develop DDS and offer implementation into exporter's practice. For example, OOO "Lesexpert" developed DDS based on the FSC standards. In this case the cost of implementation of the DDS was equal to 5-10\% of the expenses of the chain of custody FSC certification[12]. Negative evaluation of the Amendments to the Forest Code by companies could be related to general negative evaluation of recently adopted laws connected to forest sector. The reasons why companies make negative evaluation of the Amendments have been discussed intensively in official meetings (e.g. meeting of the Council of Forest Industry in the State Duma of Russian Federation [13]) and in a private discussion in public internet-sources [14]. Reasons for negative evaluation include:

- Unqualified deputies responsible for decision making in forest industry field;

- Companies consider that the burden connected to counting logged wood and declaring is excessive. Head of the Forestry Department of Russian Federation (Mr. Gagarin) noted that "counting harvested timber is an obligation of every forest logger, not an extra burden"[13];

- Amendments do not operate when wood processing takes place near the harvesting area. In such cases, roundwood becomes sawnwood during several days. It should be understood that after becoming sawnwood the timber is not under the influence of Amendments. At the same time there is a possibility to avoid filling up declaration and invoices which is obligatory for roundwood in the context of Amendments, because in fact there are no trucks with roundwood driving on the road where documentation may be controlled by police or other structures; the roundwood is not leaving the forest. This kind of situation is common in Far East and Siberia [14].

It should be noted that currently amendments to the Forest Code represent only a legal platform for appearance of real requirements related to counting, marking and transporting of wood. Currently, the amendments include only a general description of the requirements to be implemented. Real requirements should be developed in the future by the government and the Ministry of Natural Resources of the Russian Federation [15]. 
The EUTR came into force at the beginning of 2013 but did not work at its full capacity until the autumn 2013. For instance, there was no recognized Monitoring Organizations (MO) until the end of August 2013 [16]. Two monitoring organizations begun to function on the 19th August 2013 [17]: NEPCon in all EU Member States and Consorzio Servizi Legno-Sughero in Italy. Consequently, as this research was conducted in October-November 2013, there was only one organization which could develop DDS for Operators and check Operator's DDS in Europe. At the same time it is logical to suppose that it is physically impossible to control all Operators working in the European market. At the end of 2014 already 4 Monitoring Organizations existed [17].

It should be noted that national legislation in some EU countries is still under preparation as well and therefore the EUTR is not working in full effect. "The full impact of the EUTR will only be visible once the enforcement mechanisms and national legal frameworks are fully implemented according to the plan", observes Programme Manager of the NEPCon Forest Legality (Mr. Sloth) [18].

Because of lack of strict control, some Russian exporters who know the requirements of the EUTR use as an accordance measure those systems, which they decided to be appropriate as DDS. For example, as was noted by the Government Relations -director of the Archangelsk pulp-andpaper plant (Natalia Pinjagina), their company uses FSC certificate as a guarantee of legality of wood and as a passing ticket for entering the European market [16]. Possibly due to the same reason some Operators did not make any demands related to implementation of the EUTR to exporters. There is no unified form of DDS, and every Operator may interpret it in their own way.

In appearance of other MO the situation should be changed. Most probably, more active interest in the development of internal tracing systems for wood origin and usage of DDS provided by MO will appear.

In 2008 in the United States, amendments to the U.S. Lacey Act were adopted. Those amendments were related to termination of entering illegally obtained phytogenic products in the U.S. market (including wood and wood-based products). Illegally obtained products mean getting materials used for product with violation of the law, violation of the regime of specially protected natural sites, etc. Consequently, the Lacey Act and the EUTR have similar aims, and as far as a part of the Lacey Act related to illegal timber has been operating for almost 5 years, it is already possible to make conclusions about its efficiency.

According to Climate Advisers' Managing Director (Glenn Hurowitz), Lacey Act has led to the following positive consequences [19]:

- Lacey Act has helped to create jobs in the U.S. forest products industry by eliminating illegal and unfair competition. U.S. hardwood export increased by $70 \%$ while in other countries export didn't increase or even decreased;

- Contribution to decline of illegal logging worldwide consequently has helped to decrease greenhouse gas emissions;

- Saving forest areas with endangered wildlife such as tigers, orangutans, lemurs.

Probably similar results could be expected from realization of the EUTR.

Current research is based on reviewed literature related to combating against illegal logging and to the impact of the EUTR on Russian companies exporting wood and wood-based products; and on the results of the questionnaire carried out among the Russian companies exporting wood and wood-based products into EU. Utilized research methods allow us to evaluate the influence of the EUTR on the Russian exporting companies. Disadvantage of the questionnaire method used in the current research is related to the low confidence level resulting from the small number of the responses from the exporting companies.

Some of the aggregated data obtained from the questionnaire are the same as the opinions of the companies announced in their interviews or internet publications. For instance, the opinion of the 
Archangelsk pulp and paper plant regarding suitability to use FSC for implementation of the EUTR requirements is the same as the aggregated opinion of exporting companies obtained from the questionnaire. Therefore, it would be possible to assume that answers for the other questions reflect the reality.

EUTR was introduced less than 2 years ago, and there is little information how the EUTR influences exporters. Currently, there is no clear evidence that illegal timber is not entering the EU markets from Russia. It is possible to judge only through indirect evidence, such as rejected suppliers. EUTR may be addressed similarly to the opinion expressed about the amendments to the Lacey Act: "Will this law effectively influence the illegal logging? It largely depends on precedents of penalties to unfair Operators which could appear in the near future" [20].

The questionnaire used in the current research could be used again after appearance of precedents related to the unfulfilled EUTR requirements and after start of active and proper work of competent authorities and monitoring organizations. It could allow us to trace tendencies in companies' attitude towards the EUTR and changes in their business practice related to the necessity of stricter implementation of the requirements of the EUTR.

\section{Acknowledgments}

This article is based on the Master Thesis of Elena Neshataeva in the Finnish-Russian CrossBorder University (www.cbu.fi). Authors thank the Russian companies who responded to the questionnaire.

\section{References}

1. Government barometer.2012.Illegal logging issue.Retrieved from: http://barometer.wwf.org.uk/what_we_do/government_barometer/the_illegal_logging_issue/ [Cited 29 December 2013].

2. UNECE. 2013. Forest Products Annual Market Review 2012-2013.Geneva Timber and Forestry Study Paper 33. Geneva, $133 \mathrm{p}$.

3. WWF. 2008. Illegal wood for the European market. An analysis of the EU import and export of illegal wood and related products.WWF, $43 \mathrm{p}$.

4. FSC Russia.2010. Scenarii razvitija sobitii, svjazannih s Reglamentom EU № 995/2010 po protivodeistviju torgovle nezakonno zagotovlennoi drevesinoi, [Scenario of developments related to the EU Timber Regulation № 995/2010 connected to the combating trade illegally harvested timber]. Retrieved from:http://www.fsc.ru/upload/reference\%203.[Cited 10 November 2013].

5. European Comission. 2013. GUIDANCE DOCUMENT FOR THE EU TIMBER REGULATION. Retrieved from: http://ec.europa.eu/environment/forests/pdf/Final\%20Guidance\%20document.pdf [Cited 1 September 2013].

6. Godden, B. 2004. Sample Size Formulas. Retrieved from: http://williamgodden.com/samplesizeformula.pdf [Cited 02 November 2013].

7. FAO. 2012. The Russian Federation forest sector. Outlook study to 2030. Rome, 93 p.

8. Regulation (EU) No 995/2010 of the European Parlament and of the Council of 20 October 2010. 22.11.2010. Official Journal of the European Union, pp. 23-34.

9. Ministry of natural resources of the Russian Federation. 2013. Minprirodi Rossii polnost'u zavershilo rabotu nad proektom popravok k proektu federal'nogo zakona № 168903-6, 
“Ovnesenii izmenenii v Lesnoi Kodeks Rossiiskoi Federacii" [Ministry of natural resources of the Russian Federation finished developing of amendments to the draft of federal law № 168903-6 "About making amendments in Forestry Code of Russian Federation"], Retrieved from:http://www.mnr.gov.ru/news/detail.php?ID=131600 [Cited 10 November 2013].

10. WWF. 2007. Sistemi otslegivanija proishogdenija drevesini kak sredstvo predotvrashenija nelegal'nih lesozagotovok[Wood origin tracing systems as a way to prevent illegal logging]. Materiali seminara, Saint-Petersburg, 20-21 February 2007.WWF Russia, 132 p.

11. Sveza. 2013. "Sveza" razrabotala Sistemu Dolgnoi Dobrosovestnosti [Sveza developed Due Diligence System]., Retrieved from: http://www.sveza.ru/company_news/news_issue/66 [Cited 10 August 2013].

12. Lesexpert. 2013.Unificirovannaja Sistema dolgnoi dobrosovestnosti cobljudenija Evroreglamenta po lesomaterialam pri exporte produkcii iz drevesini v strani EU, [Unified due diligence system in EU Timber Regulation and export of wood and wood-based products to the EU countries]. Retrieved from:http://lesexpert.info/eutr/2013-07-05_DDS_EUTRRU_R_N46.pdf [Cited 30 November 2013].

13. Jakubov, I.2013. Lobbistov pozvali v les [Lobbysts were called to the forest]. Forestry news., Retrieved from: http://lesvesti.ru/news/power/4662/ [Cited 10 November 2013].

14. Yaroshenko, A. 2012. MPR podderzhalo razrabotannii Rosleshozom zakonoproekt o gosregulirovanii oborota kruglih materialov, [Ministry of natural resources of the Russian Federation supported draft law developed by Federal Forestry Agency related to the State monitoring of turnover of round wood], Retrieved from:http://www.forestforum.ru/viewtopic.php?t=12872 [Cited 3 September 2013].

15. Wood. 2013.V dekabre 2013 goda bili prinjati tri federal'nikh zakona, vnosjashchikh izmenenija v lesnoi kodeks RF [In December 2013 three federal laws related to making amendments in the Forest Code were adopted] , Retrieved from: http://www.wood.ru/ru/lonewsid-54781.html [Cited 10 February 2014].

16. Jakubov, I.2013. Forestry news. Retrieved from: http://www.lesvesti.ru/news/capital/6460/ [Cited 10 November 2013].

17. European Comission. 2013. Recognized Monitoring Organizations. Retrieved from: http://ec.europa.eu/environment/forests/pdf/monitoring_organisations190813.pdf [Cited 24 November 2013].

18. NEPCON. 2013. The EUTR: getting into gear or off track? Retrieved from:http://www.nepcon.net/7599/English/HOME/News_2013/120_days_with_the_EUTR/, [Cited 1 November 2013].

19. Hurowitz, G. 2013. Earth to Tea Party: Lacey Act still working., Retrieved from:http://www.huffingtonpost.com/glenn-hurowitz/earth-to-tea-party_b_3285153.html. [Cited 9 January 2014].

20. Yaroshenko, A. 2008. Kratkaja informacija o "Zakone Lacey" I ego roli v bor'be s nezakonnimi rubkami [Introduction to the Lacey Act and it's role in the combating illegal logging], Retrieved from: http://www.forestforum.ru/viewtopic.php?f=9\&t=4479 [Cited 29 December 2013].

(C) 2015 Neshataeva E.V., Karjalainen T. 